\title{
The assessment of in vitro cardiotoxic potentials for synthetic cannabinoid, AM-2201
}

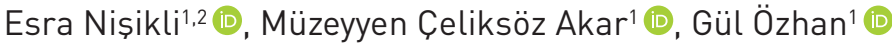 \\ 'Department of Pharmaceutical Toxicology, Faculty of Pharmacy, Istanbul University, Istanbul, Turkey \\ ${ }^{2}$ Council of Forensic of Medicine, Istanbul, Turkey
}

ORCID IDs of the authors: E.N. 0000-0002-0945-3503; M.C.A. 0000-0003-2380-7328; G.0̈. 0000-0002-6926-5723.

Cite this article as: Nișikli E, Celiksöz Akar M, Özhan G (2019). The assessment of in vitro cardiotoxic potentials for synthetic cannabinoid, AM-2201. Istanbul J Pharm 49 (3): 121-124.

\begin{abstract}
Synthetic cannabinoid abuse has become more common in recent years, although knowledge about the risk of the relatively new synthetic cannabinoid molecules is not adequate. Data is limited and analytical methods and case reports related to the clinical effects of this substance are recent and new. The studies are generally related to the cardiac effects of first defined molecules rather than every molecule in the group. The cardiac clinical effects of synthetic cannabinoid abuse and its underlying mechanisms are not certain. In this regard, this study aims to investigate AM-2201, one of synthetic cannabinoids, because knowledge related to AM-2201 is less than the others in this group. The cardiotoxicity and underlying mechanisms of AM-2201 were assessed on cardiac cell culture. The half-maximal inhibition concentration (IC ${ }_{50}$ ) values were 101.49 and 63.33 $\mu \mathrm{M}$ by WST-1 and LDH assays. AM-2201 did not induced the reactive oxygen species (ROS) levels. Correlatively, no change was observed in total antioxidant capacity (TAC) levels. As to the measurements, Annexin V-FITC and acridine orange dye, AM-2201 did not induce apoptosis and the primary cell death was necrosis. According to our results, further studies such as mechanism on cell death and cancer pathways should be investigated.
\end{abstract}

Keywords: AM-2201, apoptosis, cardiotoxicity, cytotoxicity, oxidative stress, synthetic cannabinoid

\section{INTRODUCTION}

Synthetic cannabinoids elicit cannabimimetic effects similar to $\triangle 9$-tetrahydrocannabinol $(\triangle 9$-THC) which is the primary psychoactive component of cannabis through interaction with CB1 and CB2 cannabinoid receptors. Because synthetic cannabinoids are full agonist and can bind to the CB1 receptor with an affinity greater than $\triangle 9-T H C$, they are more potent and have a longer effect than $\triangle$ 9-THC. So, they are associated with more severe and dangerous health effects than marijuana (Mckeever et al. 2015; Castellanos and Gralnik 2016).

Synthetic cannabinoids, which are considerably new molecules, were initially developed for research purposes as potential therapeutics; however, their abuse was firstly reported and gradually increased in the early 2000s (Debruyne and Boisselier 2015; Cooper 2016; Hess et al. 2016). This increase in synthetic cannabinoids abuse is attributed to intense psychoactive effects and lack of detectability in routine drug screening tests. Despite the molecules being synthetic and consisting of unknown mixtures of chemicals (mostly more than one type of synthetic cannabinoid or other drugs), users believe that the products are natural and harmless (Castaneto 2014; Ibrahim and Al-Saffar 2014; Mckeever et al. 2015; Castellanos and Gralnik 2016). In synthetic cannabinoid abuse, agitation or irritability, anxiety, confusion, psychosis, nausea and vomiting, shortness of breath, tremor, and seizures have been mostly reported (Castaneto 2014; Mckeever et al. 2015). Cardiovascular side effects such as tachycardia, hypertension, chest pain, and myocardial infarction have been reported in case reports (Aksel 2015; Atik et al. 2015). Most studies in this area have been 
about the effects of synthetic cannabinoids on the nervous system, whereas, knowledge about the toxic effects of synthetic cannabinoids on the cardiovascular system is limited. This study aims to define the toxic potentials and underlying mechanisms of AM-2201, synthetic cannabinoid, on cardiac cells.

\section{MATERIALS AND METHODS}

Cell culture conditions: The rat cardiomyoblast cell line, $\mathrm{H} 9 \mathrm{c} 2$ $\left(\mathrm{CRL} 1446^{\mathrm{TM}}\right)$, was obtained from the American Type Culture Collection (ATCC), and cultured according to the manufacturer's instructions. AM-2201 was obtained from Lipomed (JWH1503-1, Arlesheim-Swiss). AM-2201 (1 mg) was dissolved in DMSO $(27 \mu \mathrm{L})$ to prepare the stock solution (100 mM).

For all tests, the cells were seeded in 6-well or 96-well plates at a density of $2.5 \times 10^{4}$ cells $/ \mathrm{mL}$, and cultured in $37^{\circ} \mathrm{C}$ for 24 h. After pre-incubation, each well was treated with 0-100 $\mu \mathrm{M}$ AM-2201 for $48 \mathrm{~h}$. The assays and tests were done in triplicate.

Cytotoxicity: WST-1 (Roche Cell Proliferation Reagent, Germany) and LDH (Roche, Germany) assays were performed according to the manufacturer's instructions.

In WST-1 assay, after exposure to AM-2201, $10 \mu \mathrm{L}$ of the WST-1 solution was added to each well. After incubation for 30 minutes at $37^{\circ} \mathrm{C}$, the samples were analyzed using a microplate reader at 420 nm (Biotek, Epoch, Germany). In LDH assay, after exposure to AM-2201, $100 \mu \mathrm{L} /$ well supernatant was removed and transferred into a clear microplate. To determine the LDH activity in the supernatants, $100 \mu \mathrm{L}$ reaction mixtures were added to each well, and incubated for 30 minutes protected from light. Then, the absorbance of the samples were measured using microplate reader at $490 \mathrm{~nm}$. The assay medium $(200 \mu \mathrm{L})$ for background control and Triton-X solution $(100 \mu \mathrm{L})$ for positive control were added to wells containing $1 \times 10^{4}$ cells/100 $\mu$ L/well. The unexposed cells were evaluated as the negative control. To determine cytotoxicity, the absorbance values were measured using a microplate spectrophotometer system (Epoch, Germany). Then, the inhibition of enzyme activity observed in the cells was calculated with the absorbance values and compared to that of unexposed cells. The concentration-cell death (\%) curves were used to calculate the half maximal inhibition concentrations $\left(\mathrm{IC}_{50}\right)$ that are responsible for the death of $50 \%$ of the cells. The cytotoxicity was evaluated with $\mathrm{IC}_{50}$ values.

Oxidative stress: The induction of ROS production was evaluated by 2,7'-dichlorodihydrofluorescein diacetate $\left(\mathrm{H}_{2} \mathrm{DCFDA}\right)$ (Sigma-Aldrich, Germany) dye using flow cytometry (Acea Novocyte 1000, California, USA) at Ex/Em: 488/535 nm (Schupp et al. 2008). The controls and the exposed cells were adjusted to be $1 \times 10^{7}$ cells $/ \mathrm{mL}$. At least $1 \times 10^{4}$ cells in 6 -well plates were analyzed, the results were shown as percent of florescence intensity. Phosphate buffer serum (PBS) was used as a negative control. In the results, the presence of ROS was expressed as the percentage of the total cell quantity.

For TAC assay, Total Antioxidant Capacity Assay Kit (SigmaAldrich, Germany) was used according to the manufacturer's instructions. The stock Trolox solution was prepared at $1 \mathrm{mM}$ in DMSO and stored at $-20^{\circ} \mathrm{C}$. One part of $\mathrm{Cu}^{+2}$ reagent was diluted with 49 part of assay diluents for the $\mathrm{Cu}^{+2}$ working solution. The working concentrations of Trolox were 4, 8, 12, 16 and $20 \mathrm{nmol} /$ well. After exposure to AM-2201, the $\mathrm{Cu}^{+2}$ working soIution $(100 \mu \mathrm{L})$ was added to every well, and incubated for 90 min protected from light. Then, the absorbance was measured at $570 \mathrm{~nm}$ by a microplate reader. By using Trolox standard curve, the amounts of Trolox in the samples were calculated as in the following equation:

$\mathrm{TAC}_{\text {Sample }}=\mathrm{TS} / \mathrm{SA}$

Ts: sample volume added in the sample wells $(\mu \mathrm{L})$

SA: TAC amounts in the sample well calculated from standard curve (nmol)

Apoptosis: Annexin V-FITC detection kit (Biolegend, CA, USA) was used according to the manufacturer's instructions. The fluorescence intensity was measured in FITC and PI channel (at 494/518 nm (Ex/Em) for Annexin V-FTIC and 535/617 nm (Ex/Em) for PI) by flow cytometer. Necrotic cell as Annexin V/ $\mathrm{Pl}^{+}$, living cell as Annexin $\mathrm{V}^{-/ P I}$; early stage apoptotic cell as Annexin $\mathrm{V}^{+} / \mathrm{Pl}$; late apoptotic cells as Annexin $\mathrm{V}^{+} / \mathrm{Pl}^{-}$expressions appeared. The results were expressed as the percentage of total cell quantity.

Autophagy: Acridine orange dye (Sigma-Aldrich, Germany) was used (Mitou et al. 2009; Gözüaçık 2011). After exposure to AM2201, the wells were washed with PBS (1X), detached with tryp$\sin (0.2 \%)$, and then centrifuged. Then, the cells $\left(2.5 \times 10^{5}\right)$ were suspended in the cell medium, and incubated with acridine orange suspension (2\%) in the dark for 15 minutes. Finally, the absorbance value was analyzed at 488/676 nm (Ex/Em) with PerCP filter by flow cytometer. The results were expressed as the percentage of autophagy seen cells to total cell quantity.

\section{Statistical analysis}

Data were expressed as mean \pm standart error of mean (SEM). One-way ANOVA, Post Hoc and Dunnet t-test using SPSS version 23 for Windows (IBM Corp.; Armonk, NY, USA) was used to analyse the data. $p<0.05$ indicates a statistically significant difference.

\section{RESULTS AND DISCUSSION}

Despite the increasing use of synthetic cannabinoids, the reported serious adverse effects and limited toxicology data make their abuse an important public health issue. Some case reports have reported a large number of side effects on the different organs and systems. On the cardiovascular system, tachycardia, hypertension, dysrhythmia, chest pain, cardiac ischemia and myocardial infarction are common adverse clinical effects for synthetic cannabinoid abuse. Knowledge about the toxic effects of synthetic cannabinoids on the cardiovascular system is limited. Most of the studies are about the toxic effects of synthetic cannabinoids on the nervous system. Therefore, we aimed to investigate AM-2201, one of synthetic cannabinoids, because knowledge of AM-2201 is less than that of the others in this group. In addition, we evaluated the potential of cytotoxic, oxidative and apoptotic damage of AM2201 on $\mathrm{H} 9 \mathrm{c} 2$ rat cardiomyoblast cell line. 
Firstly, WST-1 and LDH assays were performed for the cytotoxic effects of AM-2201. The IC 50 values were 101.49 and $63.33 \mu \mathrm{M}$ by WST-1 and LDH assays, respectively (Figure 1). The LDH leak-
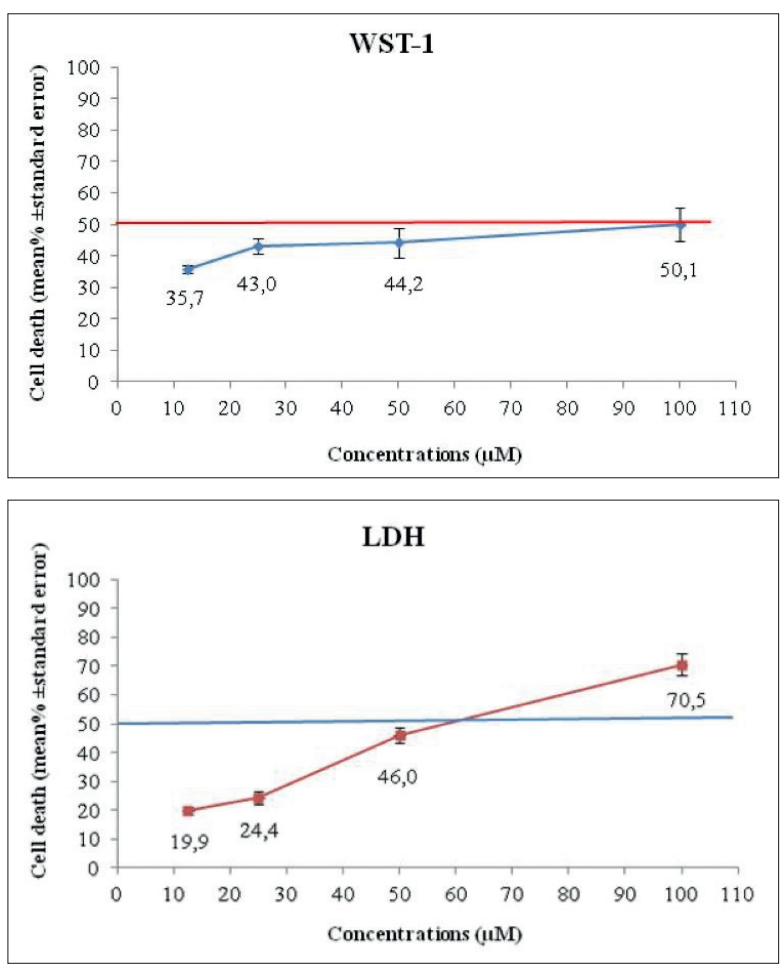

Figure 1. The effects of AM-2201 on H9c2 cell viability by WST1 and LDH.

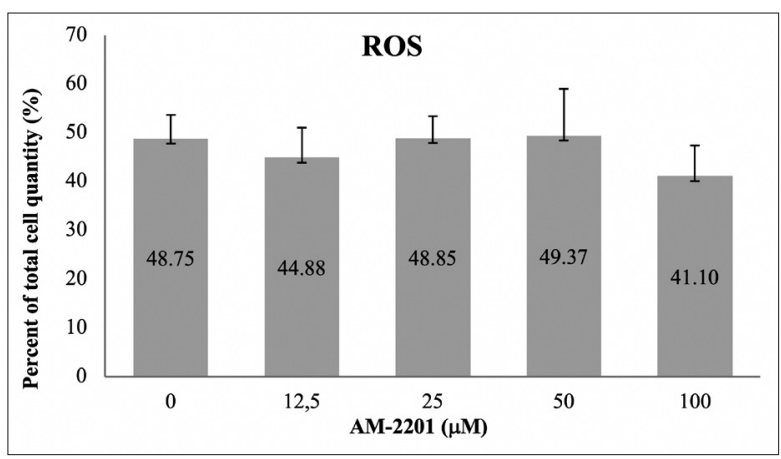

Figure 2. The ROS levels in $\mathrm{H} 9 \mathrm{c} 2$ cells exposed AM-2201 at 12.5, 25, 50 and $100 \mathrm{mM}$ concentrations.

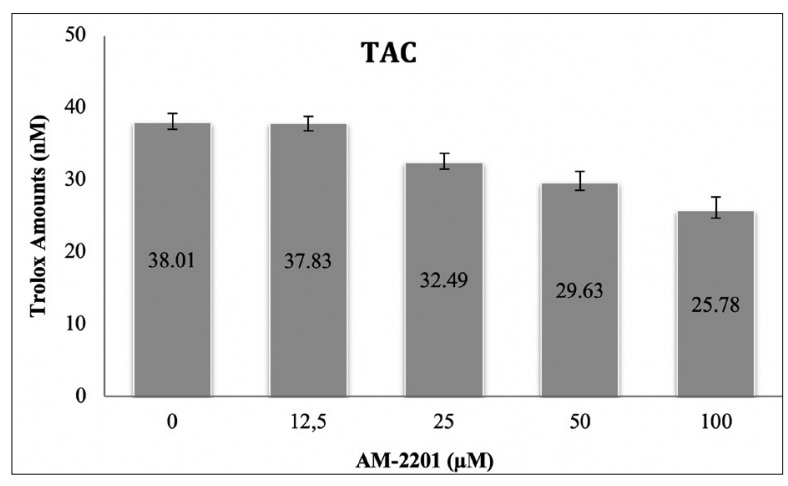

Figure 3. Total antioxidant capacity of H9c2 cells exposed AM2201 at 12.5, 25, 50 and 100 mM concentrations. age assay was observed more sensitive than WST-1 assay for AM-2201 cytotoxicity in $\mathrm{H} 9 \mathrm{c} 2$ cell line.

Tomiyama and Funada (2011) reported that CP-47,497, CP-47,497-C8 and CP-55,940 were significantly cytotoxic for 2 h exposure at $30 \mu \mathrm{M}$. CP-55,940 caused nuclear fragmentation and condensation at $30 \mu \mathrm{M}$ concentration. They also reported that their cytotoxic effects were significantly suppressed by the CB1 receptor antagonist AM-251, but not by the CB2 receptor antagonist AM-630. In the other study conducted by Tomiyama and Funada (2014), it was observed that eight synthetic cannabinoids (HU-210, CP-55,940, CP-47,497, CP-47,497C8, JWH-018, JWH-210, AM-2201, and MAM-2201) induced a significantly cytotoxic effect in a dose-dependent manner on primary mouse neuronal cells. They reported that the relative cytotoxicity levels of AM-2201 were 2.4 and 2.8 at $10 \mu \mathrm{M}$ and 30 $\mu \mathrm{M}$ AM-2201, respectively, to the control group. In comparison with our results, the primary mouse neuronal cells could be more sensitive than mouse cardiomyoblast cells to AM-2201.

In the present study, the type of cell death was determined by staining with Annexin V-FTIC-PI. At the highest concentration $(100 \mu \mathrm{M})$, early stages of apoptosis were not observed, and late apoptosis was determined to be maximum 1.17\% (data not shown). Total apoptosis results were shown in Table 1. It was observed that the necrosis ratio was maximum $12.76 \%$. At $100 \mu \mathrm{M}$ exposure, apoptosis and necrosis were increased 3 and 9.73 fold, respectively, compared to the control ( $p>0.05)$ (Table 1).

Tomiyama and Funada (2011) reported that the number of Annexin $\mathrm{V}^{+}$cells was significantly increased at $2 \mathrm{~h}$ after treatment with CP-55,940. Also, some morphological changes were induced by CP-55,940, which were reflected the necrotic or late apoptotic cells. Couceiro et al. (2016) indicated JWH-018 metabolite, $\mathrm{N}$-(3-hidroksipentil), decreased the cell via necrosis on human kidney and neuroblastoma cell lines. Similarly, we observed necrotic cell death after treatment with AM-2201.

In the present study, the ROS levels were observed to decrease $15.69 \%$ at $100 \mu \mathrm{M}$ compared to control ( $p>0.05$ ) (Figure 2). The TAC levels also decreased depending on exposure concentration, however it was not statistically significant ( $p>0.05$ ). The decrease of TAC was $\leq 32.18 \%$ at the exposure concentrations (Figure 3). However, the results should be ignored because a

Table 1. The results of apoptosis and necrosis in the H9c2 cardiomyoblast cells treated with AM2201

\begin{tabular}{|lcc|}
$\begin{array}{l}\text { Concentrations } \\
(\mu \mathrm{M})\end{array}$ & $\begin{array}{c}\text { Apoptosis } \\
\text { (mean } \% \pm \\
\text { standard error) }\end{array}$ & $\begin{array}{c}\text { Necrosis } \\
\text { (mean\% } \% \\
\text { standard error) }\end{array}$ \\
\hline Negative control & $0.31 \pm 0.03$ & $1.03 \pm 0.08$ \\
12.5 & $0.36 \pm 0.04$ & $3.94 \pm 0.07^{*}$ \\
25 & $0.48 \pm 0.06$ & $8.27 \pm 1.12^{*}$ \\
50 & $0.76 \pm 0.08^{*}$ & $7.22 \pm 1.05^{*}$ \\
100 & $0.94 \pm 0.08^{*}$ & $8.05 \pm 1.11^{*}$ \\
\hline${ }^{*} p>0.05$, one-way ANOVA, Post Hoc and Dunnet t-test. \\
\hline
\end{tabular}


high cytotoxicity level was observed at these exposure concentrations.

Rajesh et al. (2010) investigated the cell death and signal transduction pathways related to CB1 receptors activated via endocannabinoid anandamide and HU-210 (synthetic agonist) in human coroner artery endothelial cells. They reported endocannabinoid anandamide and $\mathrm{HU}-210$ increased ROS levels, and also CB1 receptor antagonist or antioxidants (acetylcysteine) decreased ROS levels. However, Almada et al. (2017) observed that WIN-55,212 decreased 16\% of cell viability in human choriocarcinoma and primer culture of placenta cytotrophoblast cells. Also, they reported that WIN 55,212 did not induce ROS formation. Similar to Almada et al. (2017), we observed that AM-2201 did not induce ROS production. However, the results were not statistically significant ( $p>0.05$ ) even if AM-2201 decreased ROS levels in rat cardiomyoblast cells.

Data about the effects of autophagy induction of synthetic cannabinoids is not available in the literature. In our study, the autophagic effects of AM-2201 were detected with acridine orange dye. In the rat $\mathrm{H} 9 \mathrm{c} 2$ cardiomyoblast cells exposed to AM-2201 during $48 \mathrm{~h}$, the autophagy ratio to total cell was determined to be $57.24-72.40 \%$. The induction was $\leq 1.28$ fold compared to control, however, the results were not statistically significant ( $p>0.05$ ) (Figure 4).

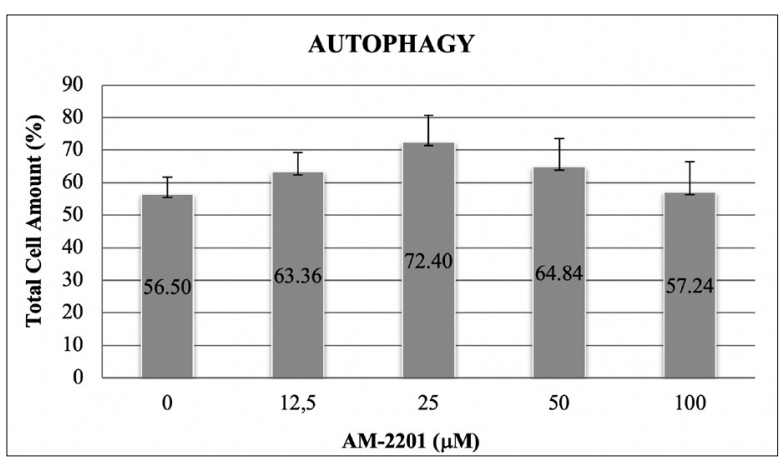

Figure 4. The autophagy-inducing potentials of AM-2201.

In conclusion, we observed necrotic cell death principally under the concentrations of $\mathrm{IC}_{50}$ values $(<63.33 \mu \mathrm{M})$. Based on our results, it could be concluded that the cardiotoxic effect of AM-2201 might be due to hypertrophic and/or arhythmogenic effects rather than direct cardiomyoblast cell death effects. Therefore, it is considered that further studies should be carried out in terms of the effects of metabolites, in hypertrophic signal pathways, and cardiac conduction pathways. Besides, knowledge of most synthetic cannabinoid packages includes multiple synthetic cannabinoid types and other psychoactive ingredients. Therefore, the investigation about interactions between synthetic cannabinoids and other drugs need to be researched.

Peer-review: Externally peer-reviewed.

Author Contributions: Concept - N.E., Ö.G.; Design - N.E., A.Ç.M., Ö.G.; Supervision - Ö.G.; Resource - N.E., Ö.G.; Materials - N.E., A.Ç.M., Ö.G.; Data Collection and/or Processing - N.E., A.Ç.M., Ö.G.; Analysis and/or Interpretation - N.E., A.Ç.M., Ö.G.; Literature Search - N.E., Ö.G.; Writing - N.E., Ö.G.; Critical Reviews - N.E., A.Ç.M., Ö.G.
Conflict of Interest: The authors have no conflict of interest to declare.

Financial Disclosure: The work was supported by the Research Fund of Istanbul University (Project no: 21787).

\section{REFERENCES}

Aksel G, Oner Bozan O, Kayacı M, Guneysel O, Sezgin SB (2015). Rising threat; bonsai. Turk J Emerg Med 15: 75-78. [CrossRef]

Almada M, Costa L, Fonseca BM, Amaral C, Teixeirab N, Correia-da Silva G (2017). The synthetic cannabinoid WIN-55,212 inducedapoptosis in cytotrophoblasts cells by a mechanism dependent on CB1 receptor. Toxico/ 385: 67-73. [CrossRef]

- $\quad$ Atik SU, Dedeoğlu R, Varol F, Çam H, Eroğlu AG, Saltık L (2015). Cardiovascular side effects related with use of synthetic cannabinoids "bonzai": two case reports. Turk Pediatri Ars 50: 61-64. [CrossRef]

- Castellanos D and Gralnik LM (2016). Synthetic cannabinoids 2015: an update for pediatricians in clinical practice. World J Clin Pediatr 5: 16-24. [CrossRef]

- Castaneto MS, Gorelick DA, Desrosiers NA, Hartman RL, Pirard S, Huestis MA (2014). Synthetic cannabinoids: epidemiology, pharmacodynamics and clinical implications. Drug Alcohol Depen 144: 12-41. [CrossRef]

- Cooper ZD (2016). Adverse effects of synthetic cannabinoids: management of acute toxicity and withdrawal. Curr Psychiatry Rep 18: 52-71. [CrossRef]

- Couceiro J, Bandarra S, Sultan H, Bell S, Constantino S, Quintas A (2016). Toxicological impact of JWH-018 and its phase I metabolite N-(3-hydroxypentyl) on human cell lines. Forensic Sci Int $\mathbf{2 6 4}$ 100-105. [CrossRef]

- $\quad$ Debruyne D and Boisselier RL (2015). Emerging drugs of abuse: current perspectives on synthetic cannabinoids. Subst Abuse Rehabil 6: 113-129. [CrossRef]

- Gözüaçık D (2011). Otofaji analiz yöntemleri ve uygulama aşamaları. In S. Koçtürk \& H. S. Vatansever, eds. Hücre Ölümü Araştırma Teknikleri. İzmir: Dokuz Eylul University Press, 129-141.

Hess C, Schoeder CT, Pillaiyar T, Madea B, Müller CE (2016). Pharmacological evaluation of synthetic cannabinoids identified as constituents of spice. Forensic Toxico/ 34: 329-343. [CrossRef]

- Ibrahim S, Al-Saffar F, Wannenburg T (2014). A unique case of cardiac arrest following K2 abuse. Case Reports in Cardiology Article ID 120607: 1-3. [CrossRef]

- McKeever RG, Vearrier D, Jacobs D, LaSala GL, Okaneku J, Greenberg MI (2015). K2-not the spice of life; synthetic cannabinoids and ST elevation myocardial infarction: A case report. J Med Toxicol 11: 129-131. [CrossRef]

- Mitou G, Budak H, Gozuacik D (2009). Techniques to study autophagy in plants. Int J Plant Genom 2015, Article ID 451357: 1-14. [CrossRef]

- $\quad$ Rajesh M, Mukhopadhyay P, Haskó G, Liaudet L, Mackie K, Pacher $P$ (2010). Cannabinoid-1 receptor activation induces reactive oxygen species-dependent and -independent mitogen-activated protein kinase activation and cell death in human coronary artery endothelial cells. Br J Pharmacol 160: 688-700. [CrossRef]

- Tomiyama K and Funada M (2011). Cytotoxicity of synthetic cannabinoids found in "Spice" products: The role of cannabinoid receptors and the caspase cascade in the NG 108-15 cell line. Toxicol Lett 207: 12-17. [CrossRef]

- Tomiyama K and Funada M (2014). Cytotoxicity of synthetic cannabinoids on primary neuronal cells of the forebrain: the involvement of cannabinoid CB1 receptors and apoptotic cell death. Toxicol Appl Pharmacol 274: 17-23. [CrossRef] 